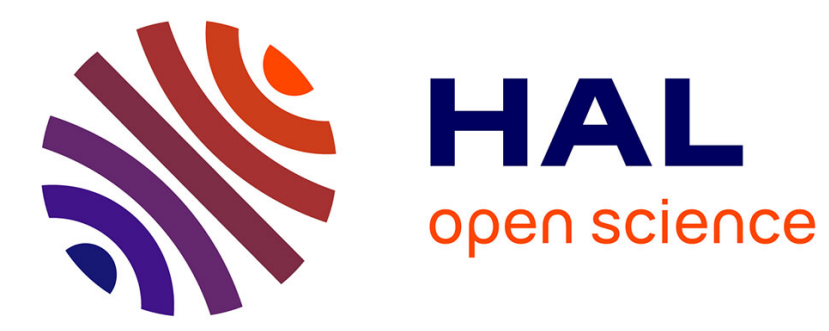

\title{
New Viscosity Data for CuO-water Nanofluid -The Hysteresis Phenomenon Revisited
}

\author{
Nguyen Cong Tam, Nicolas Galanis, Thierry Maré, Erwan Eveillard
}

\section{To cite this version:}

Nguyen Cong Tam, Nicolas Galanis, Thierry Maré, Erwan Eveillard. New Viscosity Data for CuOwater Nanofluid -The Hysteresis Phenomenon Revisited. Advances in Science and Technology, 2010, 81, pp.101-106. 10.4028/www.scientific.net/AST.81.101 . hal-00992604

\section{HAL Id: hal-00992604 https://hal.science/hal-00992604}

Submitted on 25 Mar 2015

HAL is a multi-disciplinary open access archive for the deposit and dissemination of scientific research documents, whether they are published or not. The documents may come from teaching and research institutions in France or abroad, or from public or private research centers.
L'archive ouverte pluridisciplinaire HAL, est destinée au dépôt et à la diffusion de documents scientifiques de niveau recherche, publiés ou non, émanant des établissements d'enseignement et de recherche français ou étrangers, des laboratoires publics ou privés. 


\section{New Viscosity Data for CuO-water Nanofluid -The Hysteresis Phenomenon Revisited}

Cong Tam Nguyen, Nicolas Galanis, Thierry Maré and Erwan Eveillard

Keywords: Nanofluids, CuO-Water nanofluid, Thermal properties, Dynamic viscosity, Hysteresis, Stability

Abstract. In the present work, we have experimentally investigated the stability and hysteresis behaviors of CuO-water nanofluid when submitted to a repeated heating and cooling process. Data has shown that for a low particle volume concentration, $1.6 \%$ in particular, the hysteresis phenomenon did not occur for the temperature range considered. For a higher particle concentration,

$5 \%$ in particular, the hysteresis behaviour was clearly observed when fluid temperature exceeded $52^{\circ} \mathrm{C}$ approximately. Beyond this critical temperature, the nanofluid viscosity has increased, and such an increase even continued with a decrease of temperature during the cooling phase.

Subsequent measured viscosity and observations in laboratory after the first occurrence of the hysteresis phenomenon have confirmed that the alterations on the particle suspension and on the nanofluid stability appear indeed permanent. Such alterations were found to worsen with further heating/cooling cycles.

\section{Conclusion}

We have experimentally studied the stability and hysteresis behaviors of CuO-water nanofluid. It was found that for the nanofluid with $1.6 \%$ particle volume fraction, the hysteresis phenomenon did not occur, and the effects due to the heating/cooling process, although present, seem to be slight.

For a higher particle concentration, $5 \%$, the hysteresis behaviour was clearly observed when fluid temperature exceeded $52^{\circ} \mathrm{C}$ approximately. Measured viscosity data and observations after the first occurrence of the hysteresis phenomenon have confirmed that the damages due to repeated heating/cooling cycles on the particle suspension and on the nanofluid stability appear indeed permanent. Such damages were found to become worsened with further heating/cooling cycle. References 